\title{
Parental Socio-Economic Status and Higher Academic Aspiration of Senior Secondary School Students in Cross River State Nigeria
}

\author{
Dr. Joseph Etiongbie Ogbiji \\ Faculty of Education \\ Cross River University of Technology \\ Email:jeogbiji@gmail.com Tel: 2348064854436
}

Received: October 1, 2018 Accepted: October 20, $2018 \quad$ Published: October 31, 2018

doi:10.5296/jet.v5i2.14148 URL:http://dx.doi.org/10.5296/jet.v5i2.14148

\begin{abstract}
This study sought to investigate the influence of parental socio-economic status (SES) on higher academic aspiration among senior secondary school students in Cross River State of Nigeria with emphasis on Ogoja Education Zone. To do this, three research questions and three hypotheses were formulated to guide the study. The research questions were based on three variables of parental educational status, occupation and material wealth. The research instrument was a 17 item researcher-made "Parental Socio-economic status and higher academic aspiration of senior secondary school students questionnaire". It was built on a four-point modified Likert scale. Samples comprised of 600 senior secondary three (SS3) students at the rate of 30 per school from the five local government areas in the education zone. Data were analyzed using simple percentages. The result of research question one which sought to determine the influence of parental educational status on their children's higher educational aspirations shows that $72.16 \%$ of the respondents affirmed that parental educational status has significantly high influence on their wards educational aspiration. Research Question two was on the influence of Parental occupation on their children's academic aspiration. It had a positive response of $37.99 \%$ which shows negative influence. The finding on Research Question three shows that $62 \%$ of the respondents were positive about the influence of parental material wealth on their academic aspiration. Based on the above findings conclusion and recommendations were drawn.
\end{abstract}

Keywords: socio-economic status, academic aspiration, senior secondary school

\section{Introduction}

Family background has often been considered an influential factor in the aspiration of the offspring of the family. Children whose parents are active politicians, business men/women, 
artisans, farmers etc are deemed to be greatly influenced by their parental occupations in their choice of career. Also several studies have been carried out to determine the influence of parental socio-economic status and vocational aspirations of their children. Some of these studies are done at the primary school level, while others are at the secondary school level. We shall examine the findings of some of those researches to see how they will apply to this study.

In their paper "Parental socio-economic status as predictor of Vocational Aspiration of secondary school students in Nigeria: implication for peace, curriculum Planning and Special Education", Obiyo and Eze (2015) observed that researches have always associated the educational aspirations of students to the socio-economic status (SES) of their parents. In a study involving a random selection of 400 students from 20 secondary schools in the Nsukka Education Zone of Enugu State, Nigeria, the findings disclosed that the educational status of parents as well as their financial background has no significant influence on the educational aspirations of their secondary schools wards. They rather found out that vocational aspirations of students are influenced by their interest in a course, their like for subject teacher, peer influence and the environment.

The situation in India appears to be different from the findings of Obiyo etal (2015) in Nigeria. In India, Salgotra and Roma (2018) studied a population of $35110^{\text {th }}$ class students of government secondary schools from Jamu District of Jamu and Kashmir State, they found out that the SES of parents holds a strong influence on their wards aspirations. They concluded, "Adolescents aspirations and intentions regarding higher education are strongly influenced by their socio-economic background. Socio-economic background is the major factor in the variation in students' perspectives on the value and attainability of higher education "(P. 26).

The situation in Australia is similar to that of India where Cosidine and Zappala (2002) found out that socio-economic status of parents significantly influences the educational background of students from disadvantaged background. These students are found to exhibit low literacy, retention and understanding; non-attendance of higher institutions and a show of negative attitude to school. Similarly, Gore, Holmes, Smith, Southgate and Albright (2015) did a more robust study comprising 3504 students at different levels of secondary schools and came out with more complex results. They found out that their students' academic aspirations changed over time, especially due to their prior academic achievements. For instance "Primary Pupils were significantly less tentative about careers they might pursue than students in secondary schools "P. 171. Gore et al (2015) found out that prior academic achievement was a stronger factor to SES in determining the career aspirations of students, and that student with high academic achievement in the past were attracted to prestigious jobs and showed a lack of certainty of a definite career they might wish to undertake due to many options available to them.

In a similar study in Bangladesh, Malaysia, Shahidul, Karim and Mustari (2015) found out that students academic aspirations were significantly influenced by the socio-economic background of the family and the resources of the schools. Specifically they pointed out that family social capital impacts higher than the school social capital. By family capital, they implied parents attendance of schools activities, their show of assistance in their wards home 
work, their educational expectations from their wards and their discussions of the future career of their wards. And by school social capital they implied student-teacher relationship, students' involvement in extracurricular activities, existence of experienced and well-trained teachers. Studies with similar findings are those of Mizza, Darusalam and Ismail (2017) and Eshetu (2015). Contrary to the findings of Gore et al (2015), Shahidul et al (2015) from Australlia and Malaysia, respectively which significantly linked students academic aspiration and achievements to their socio-economic background, the study of Machehe and Ifelunni (2014) among secondary school students in Enugu State, Nigeria, seems to differ. They found out from a study of 180 students in the state secondary schools that parental socio-economic status and academic background are statistically insignificant to students academic performances. They however affirmed that parental educational qualifications and students' health status are factors that are significant to the academic achievements of students. Similar studies conducted by Koskei, and Ngeno (2015), Gabriel, Muli, Muasya, Maonga and Makhungilhu (2016) found out that family socio-economic background of students significantly influences their vocational and academic aspirations.

Also, Adesina and Okewole (2014) just like Kainuwa and Yusuf (2013) are of the opinion that parents socio-economic status and educational background strongly influence their wards' academic performance and aspirations, as students from high SES families perform better in school than those from low SES families. The above position of scholars may not hold sway in all situations as observations has shown that genetic inheritance such as the intelligence quotience (IQ) plays a significant influence in the academic achievement and aspirations of students.

\section{Statement of the Problem}

Cross River State is one of the 36 states of Nigeria. It is an agrarian community with more than 80 percent of its approximately four million people living in the rural areas (NPC, 2018). Most of the literature reviewed did not cover Cross River State. It can therefore not be said with certainty that what obtains in other researches also apply to Cross River State. This research therefore sets out to determine the extent to which Parental Socio-economic status influences the academic aspiration of their children in senior secondary schools in Cross River State.

\subsection{Purpose of the Study}

In this study an endeavour was made to ascertain:

(a) The extent to which parental educational level influences student's academic aspirations.

(b) The extent to which Parental occupation influences students' academic aspirations.

(c) The extent to which Parental Level of material wealth influences students academic aspirations. 
2.2 Research Questions

The following research questions were used to test the data collected at 0.05 level of significance.

1. To what extent does parental educational level influence the educational aspiration of their children in senior secondary school in Cross River State?

2. To what degree does parental occupation influence the education aspiration of their children at the senior secondary school levels in Cross River State?

3. To what level does parental material wealth influence the educational aspiration of their wards at the senior secondary school level in Cross River State?

\subsection{Research Area}

This research was carried out in Ogoja Education Zone of Cross River State. This is one of the three education zones of Cross River State. The area has a projected population of about 1.3 million people with a total of 84 public secondary schools and 75 private secondary schools. Tertiary educational institutions located within the area are campuses of the Cross River University of Technology located at Ogoja and Okuku, the Federal College of Education at Obudu and the State school of nursing located at Ogoja and Obudu. Administratively, the zone is divided into five local government areas of Bekwarra, Obanliku, Obudu, Ogoja and Yala. The area is one of the food baskets of Nigeria, famous for the production of yam, cassava, rice, groundnut and cash crops like cocoa and oil palm produce.

\subsection{Research Procedure}

The study used the descriptive survey research design to sample 120 final year students from public secondary school in each of the five local government areas in the zone, Four schools were selected from each local government area out of which 30 students were sampled, comprising of 20 boys and 10 girls from each school, thus giving a total of 600 respondents.

\subsection{Instrumentation}

The instrument used for the data collection was a research-made questionnaire tagged "Parental socio-economic status and students Educational Aspiration Questionnaire". The instrument comprised of two part. Part A indentified the bio-data of the respondents such as name of school, location, class, sex and parental occupation, Part B which comprised of 17 response items was based on the three research questions. Research question one comprised of 7 items while 2 and 3 comprised of 5 items each. The response items were based on the four-point modified Likert Scale of strongly Agree, Agree, Disagree and Strongly Disagree, weighing 4, 3, 2, and 1 respectively. The instrument was validated by two research experts from the Faculty of Education, Cross River University of Technology, Calabar. It was the expert validation that reduced the response items from 20 to 17. Direct Delivery Technique, was used to sample 30 final year students from each of the 20 senior public secondary schools used for the study. The researcher collected data from 8 schools while three research 


\section{Macrothink

assistants were used in the remaining 12 schools. This was after they were adequately instructed on what to do.

Percentage (\%) was used in analyzing the data collected for the three research questions.

\section{Results}

Research Questions 1: To what extent dos parental educational status influence their children's academic aspiration at the senior secondary school level in Cross River State?

Table 1. Summation of Percentage Distribution of Responses on Research Question One

\begin{tabular}{|l|l|l|}
\hline Response Scales (R) & Summation of Response Frequencies (F) & Computed \% \\
\hline SA & 237 & 39.5 \\
\hline A & 196 & 32.66 \\
\hline SD & 98 & 16.33 \\
\hline D & 69 & 11.50 \\
\hline TOTAL & $\mathbf{6 0 0}$ & $\mathbf{1 0 0}$ \\
\hline
\end{tabular}

\section{Research Question 2}

To what extent does parental occupation influence the educational aspiration of their wards at the senior secondary school level in Cross River State.?

Table 2. Summation of Percentage distribution of responses on Research Questions Two

\begin{tabular}{|l|l|l|}
\hline Responses Scales (R) & Summation of Response Frequencies (F) & Computed \% \\
\hline SA & 140 & 23.33 \\
\hline A & 88 & 14.66 \\
\hline SD & 208 & 34.66 \\
\hline A & 164 & 27.33 \\
\hline TOTAL & $\mathbf{6 0 0}$ & $\mathbf{1 0 0}$ \\
\hline
\end{tabular}

\section{Research Question 3}

To what extent does parental material wealth influence the educational aspiration of their children at the senior secondary school level in Cross River State.?

Table 3. Summation of Percentage distribution of responses on Research Question Three

\begin{tabular}{|l|l|l|}
\hline Responses Scales (R) & Summation of Response Frequencies (F) & Computed \% \\
\hline SA & 218 & 36.33 \\
\hline A & 154 & 25.66 \\
\hline SD & 138 & 23.00 \\
\hline A & 90 & 15.00 \\
\hline TOTAL & $\mathbf{6 0 0}$ & $\mathbf{1 0 0}$ \\
\hline
\end{tabular}


4. Discussion of Findings

Two of the findings to the three research questions in this study show that parental educational status and parental material wealth greatly influence higher educational aspiration of their children. These findings are in respect of research questions one and three respectively. The findings of research question two shows that parental occupation has no significant influence on the higher educational aspiration of their wards.

Research question one sought to determine whether the educational status of parents has any significant influence on their children's educational aspiration. The summation of "strongly agree" and "agree" is $72.16 \%$ as against $27.84 \%$ for "strongly disagree" and "disagree". This findings goes to prove that preponderance of senior secondary school students in Ogoja Education Zone of Cross River State, Nigeria, are of the view that offspring of parents with higher education are more inclined to pursue higher education than those whose parents do not posses higher educational qualification. This belief may be based on their own personal experience and those of their school mates. This findings is similar to those of Cosidine and Zappala (2002) in Australia, Shahidul, Karim and Mustari (2018) in India. The finding disagrees with that of Obiyo and Eze (2015) in Enugu State of Nigeria which disassociated the educational aspiration of senior secondary school students from the educational and financial status of their parents. The findings of this research question appears realistic in the sense that most parents with higher educational qualification would want their children to be like them and even surpass them educationally. Also, most children from educated parents see education as a heritage from their parents.

The findings of research questions two however shows that parental occupation has no significant influence on the educational aspiration of their wards. The decision is based on $37.99 \%$ of the respondents who agreed that the occupation of their parents has significant influence on their educational aspiration as against $62.01 \%$ who disagree. This finding agrees with that of Obiyo and Eze (2015) in Nsukka Education Zone of Enugu State, Nigeria. The finding to research question two is contrary to the findings of Shahidul et al (2015) in Bangladish, Gore et al (2015) in Australia and Adesina and Okewole (2014) in Nigeria. It however agrees with the findings of Machehe and Ifelunni (2014) in Enugu State, Nigeria.

The reason for the finding being different from other studies conducted in countries outside Africa may not be far-fetched. While these countries are relatively more advanced educationally and technologically than Nigeria and Parental socio-economic status has a significant impact on the aspiration of their children, the reverse is the case in Nigeria where about $70 \%$ of the population is still engaged in peasant agriculture. Children from such families may not be motivated by their family occupation in their choice of career. They would want to make a change from their parental background.

The findings of research question three shows that parental material wealth has significant influence on the educational aspiration of their children. From the data computed, those who "strongly agree" and "agree" have $62 \%$ of the responses, while those with negative view accounted for $38 \%$ of the responses. From the Nigerian socio-economic environment, this finding appears realistic because, apart from the Universal Basic Education Programme, all 
other levels of education charge fees. Apart from students ability to pass the examination required for progression to another level, the ability of the parents to pay the prescribed fees is a stronger determinant for educational advancement. Before the introduction of the Universal Basic Education Programme in Nigeria in 1999, many school-age children could not attend primary or junior secondary school because of their parents inability to pay their school fees.

The findings is also similar to that of Salgotra and Roma (2018) in Jamu and Kashmir state of India and that of Gore, Holmes, Smith, Southgate and Albright (2015) who added that previous academic achievement was a stronger motivation for higher academic aspiration than Parental SES. Shahidul, Karim and Mustapha (2015) studied the influence of Parental SES vis-à-vis school resources on students academic aspiration in Malaysia and concluded that the family SES was a more potent factor than all others.

\section{Conclusion}

Based on the findings of this study, it could be concluded that parental SES has great influence on the aspiration for higher education of their children. The most significant of these factors are the educational attainment of parents, their occupation and their economic viability. Secondary school students draw a great deal of inspiration for their life pursuit from their family background. Some inspirations are negative especially for those from low socio-economic background. While most secondary school students from such a background would like to make a difference, others from high SES would want to replicate it in their lives. Other factors such as academic achievements, school resources and peer group influence equally have significant influence in the higher educational aspiration for senior secondary school students.

\section{Recommendations}

From the findings of this research, it becomes pertinent to make the following recommendations which are aimed at mitigating the influence parental SES on the higher academic aspiration of their wards especially in an agrarian and low-socio-economic society like Nigeria:

1. Government should understand that higher education is the right of citizens just like basic education.

2. Government should work assiduously towards removing man-made hindrances to higher education from those who possess the ability and the desire to pursue higher education through the introduction of scholarships and loan to deserving students.

3. Effort should be made by the government in power to improve living standard through the introduction of minimum living standard, improvement in agriculture, industrialization, infrastructural development and gainful employment for citizens.

4. Government should ensure social justice, the rule of law and mitigation of corruption from the land. 
5. Tertiary educational institutions should introduce "study work programme" so that indigent students could earn some money by working on some development project as casual staff and fund their own education.

\section{References}

Adesina, A.D., \& Okewole, J. O (2014). Correlates of Socio-economic Background and academic performance of senior secondary school students using advanced organizer learning strategy. Journal of Educational and social Research, 4/3, 89-97.

Cosidine, G., \& Zapala, G (2002). Factors influencing the educational performance of students from disadvantaged Background. Retrieved from http:creativecommons.org/ licenses/by-nc-nd/4.0.net.2/09/18.

Eshetu, A. A. (2015). Parental Socio-economic status as determinant factor in academic performance of students in Regional Examination: A case study of Dessie Town, Ethiopia. International Journal of Academic Research in Education and Review, 3/9, 247-256.

Gabriel, M. N., Muli, N.L., Muasya, I., Maonga I., \& Makhungulu, M. (2016). Parental Socio-economic Status and Academic Achievement in selected secondary schools in urban informal settlements in Westlands Division, Nairobi country. Journal of Education and social science, 3/1, 43-55

Gore, J., Holmes, K., Smith, M., Southgate E., \& Alright, J. (2015). Socio-economic status and career Aspiration of Australian students: Testing Enduring Assumptions. The Australian Educational Researcher, 42/2, 155-177.

Kainuwa, A., \& Yusuf, N. (2013): "Influence of Socio-economic and educational Background of parents on their children's' education in Nigeria. International Journal of Scientific and Research Publications, 3/10, 1-8.

Koskei, B. K., \& Ngeno, G. (2015). Parental Educationbal Attainment and students Academic Performance of Public and mixed Day schools in Kuresoi sub-country, Nakuru country, Kenya. International Journal of Innovative Research and Development, 4/1, 303-307

Machehe, C. H., \& Ifelunni, C.O. (2014). Influence of socio-economic status on Academic Acheivement of students in selected secondary schools in Nigeria: A case study of Enugu State. Journal of Education and Practice, 5/2, 105-110.

Muzzam, M., Darusalam, G.B., \& Ismail, M.I. (2017). Parental socio-economic status and Academic performance of secondary school students in the Western province of the Republic of Zambia. Retrieved 30th July 2018, from https:www.researchgate.net/publication31991360

N.P.C. (2018). National Population Commission, Calabar Office, Nigeria.

Obiyo, N.O., \& Eze, C.O. (2015). Parental Socio-economic status as predicator of vocational Aspirations of secondary school students in Nigeria: Implications for peace, 
curriculum planners and special educators. International Journal of Curriculum and Instruction, 7/2, 18-34.

Salgotra, A.K., \& Roma, K. (2018). Educational Aspiration and socio-economic status among secondary school students. Journal of Humanities and Social Sciences, 23/3, 25-29.

Shahidul, S. M., Karim, A.H., \& Mustari, S. (2015). Social capital and Educational Aspirations of secondary schools students: Does family social capital affect more compared to school social capitals? International Education Studies, 8/2, 255-260.

\section{Copyright Disclaimer}

Copyright reserved by the author(s).

This article is an open-access article distributed under the terms and conditions of the Creative Commons Attribution license (http://creativecommons.org/licenses/by/3.0/). 